\title{
Perbandingan Tingkat Akurasi Metode Average Based Fuzzy Time Series Markov Chain dan Algoritma Novel Fuzzy Time Series
}

\author{
Syavira Habib Al-adawiyah*, Evawati Alisah, Abdul Aziz \\ Program Studi Matematika, Universitas Islam Negeri Maulana Malik Ibrahim Malang, Indonesia \\ Email: syavirahabib@gmail.com*, evawatialisah@mat.uin-malang.ac.id,abdulaziz@mat.uin-malang.ac.id
}

\begin{abstract}
Abstrak
Metode fuzzy time series digunakan untuk meramalkan keadaan data perkembangan harga pangan misalnya beras. Perannya sebagai bahan makanan pokok menyebabkan beras menjadi salah satu indikator pertumbuhan ekonomi. Pentingnya menekan harga beras supaya stabil dapat dilakukan dengan peramalan terhadap harga beras di Indonesia pada masa mendatang. Metode yang digunakan untuk peramalan dalam penelitian ini adalah metode Average Based Fuzzy Time Series Markov Chain dan Algoritma Novel Fuzzy Time Series. Peneliti membandingkan kedua metode pada kasus harga beras dengan melihat tingkat akurasi yang lebih baik. Data yang digunakan dalam penelitian ini adalah data rata-rata harga beras bulanan di tingkat perdagangan besar mulai bulan Januari 2015 hingga Maret 2021 dalam satuan Rp/kg sebanyak 75 data. Hasil perbandingan tingkat akurasi menggunakan nilai Mean Absolute Percentage Error (MAPE), diperoleh peramalan rata-rata harga beras ditingkat perdagangan besar Indonesia untuk metode Average Based Fuzzy Time Series Markov Chain yaitu 0.36\%, sedangkan nilai MAPE untuk metode Algoritma Novel Fuzzy Time Series yaitu $0.19 \%$. Berdasarkan hasil MAPE dapat disimpulkan bahwa metode Algoritma Novel Fuzzy Time Series menghasilkan tingkat akurasi lebih baik dibandingkan dengan metode Average BasedFuzzy Time Series Markov Chain.
\end{abstract}

Kata kunci: Algoritma Novel Fuzzy Time Series, Average Based Fuzzy Time Series Markov Chain, harga beras, MAPE, perbandingan akurasi.

\begin{abstract}
Fuzzy time series method can be applied in predicting the situation in food price development data such as rice. The position of rice as a staple food has resulted in this commodity being one of the indicators of economic growth. The importance of suppressing rice prices so that they are stable can be done by forecasting rice prices in Indonesia in the future. The research method used for forecasting is average based fuzzy time series Markov chain and novel algorithms fuzzy time series. Researchers will compare the two methods in the case of rice prices by looking at the level of accuracy that is better. The data used in this study is the average monthly rice price at the wholesale trade level from January 2015 to March 2021 in units of $\mathrm{Rp} / \mathrm{Kg}$ as much as 75 data. The results of the comparison of the level of accuracy using the value of Mean Absolute Percentage Error (MAPE), obtained the forecast of the average price of rice at the Indonesian wholesale trade level for average based fuzzy time series Markov chain which is $0.36 \%$, while the MAPE value for novel algorithm fuzzy time series is $0.19 \%$. Based on the MAPE results, it can be concluded that the novel algorithm method fuzzy time series produces a better level of accuracy compared to the method average based fuzzy time series Markov chain.
\end{abstract}

Keywords: Novel Algorithm Fuzzy Time Series, Average Based Fuzzy Time Series Markov Chain, rice price, MAPE, accuracy comparison

\section{PENDAHULUAN}

Peramalan merupakan cara menganalisis suatu kejadian yang akan terjadi berdasarkan data yang relevan di masa lalu [1]. Metode peramalan yang banyak dikembangkan adalah time series. Time series atau runtun waktu adalah rangkaian pengamatan mengenai data terurut yang 
dianalisis menggunakan pola keterhubungan antara variabel penelitian dengan variabel waktu yang dicatat secara beruntun [2]. Metode analisis time series memiliki beberapa pilihan dalam peramalan data, seperti ARIMA, SARIMA, smoothing, dan lain-lain, namun metode ini membutuhkan data historis dalam jumlah besar dan asumsi-asumsi yang harus dipenuhi [3]. Seiring dengan perkembangan metode time series, banyak pilihan metode yang digunakan untuk menganalisis data time series, salah satunya menggunakan fuzzy time series. Fuzzy time series merupakan sebuah konsep baru yang dikemukakan oleh Song dan Chissom [4] berdasarkan teori himpunan fuzzy dan konsep variabel linguistik [5]. Himpunan fuzzy yang terdapat dalam himpunan semesta dari data aktual digunakan untuk mengubah data historis yang akan diprediksi, sehingga apabila dibandingkan dengan metode peramalan lainnya, fuzzy time series tidak memerlukan asumsi-asumsi saat data historis terbatas dan pola data tidak menjadi pertimbangan [6].

Peramalan menggunakan metode fuzzy time series telah dikembangkan, seperti yang dibahas oleh Tsaur [7] mengenai penerapan metode fuzzy time series Markov chain pada data nilai tukar dolar. Metode fuzzy time series Markov chain menggunakan rantai Markov untuk memperoleh hasil peramalan dengan peluang transisi dan meminimalkan pengaruh data yang berfluktuasi dengan mengklasifikasikan data sesuai periode. Kelebihan dari fuzzy time series Markov chain, yaitu dapat menganalisis data time series dengan sampel kecil supaya tingkat akurasi peramalan lebih tinggi dengan mengubah data historis menjadi Fuzzy Logical Relationship Group (FLRG) yang kemudian digunakan untuk memperoleh matriks probabilitas transisi rantai Markov [8]. Peningkatan akurasi metode fuzzy time series terus-menerus dilakukan dengan menggabungkan beberapa metode yang terlebih dahulu diteliti kesesuaiannya dengan kaidah matematis yang cocok [9]. Metode yang dikembangkan oleh Jasim [10] juga dapat digunakan untuk peramalan menggunakan metode fuzzy time series, yaitu algoritma novel fuzzy time series. Metode algoritma novel fuzzy time series menggunakan tahap-tahap yang cukup berbeda dari fuzzy time series klasik dalam menentukan panjang interval, sedangkan untuk memperoleh hasil peramalan metode ini memperhatikan data dari dua periode sebelumnya sehingga didapatkan hasil peramalan yang mendekati nilai data aktual.

Pemilihan interval metode fuzzy time series masih bergantung pada ketentuan yang ditetapkan oleh peneliti. Penentuan panjang interval pada metode fuzzy time series sangat berpengaruh dalam proses pembentukan Fuzzy Logical Relationship (FLR) yang nantinya juga mempengaruhi pembentukan Fuzzy Logical Relationship Group (FLRG) dan hasil akhir peramalan. Penting untuk menentukan panjang interval yang tepat supaya FLR yang terbentuk juga akurat. Salah satu metode yang dinilai efektif untuk menentukan panjang interval adalah average based [11]. Metode average based dapat mengatasi kekurangan metode-metode sebelumnya, antara lain jumlah data minimum yang dibutuhkan, periode peramalan yang pendek, adanya zero mean dan zero variance dalam pengolahan data, serta proses perhitungan peramalan yang memiliki banyak tahapan sehingga tingkat efisiensi rendah. Penerapan metode average based selain dapat digunakan pada metode fuzzy time series Markov chain juga dapat digunakan pada metode algoritma novel fuzzy time series. Metode tersebut diterapkan dalam meramalkan suatu keadaan dengan data yang sering digunakan yaitu Indeks Harga Saham Gabungan (IHSG), data manajemen keuangan, dan perkembangan harga pangan misalnya beras [12].

Karena menjadi makanan pokok, beras menjadi salah satu indikator pertumbuhan ekonomi maupun tingkat kemakmuran masyarakat [13]. Badan Pusat Statistik (BPS) mencatat rata-rata produksi padi Indonesia pada tahun 2019 sekitar 54,60 juta ton GKG (Gabah Kering Giling) dengan konsumsi beras mencapai 154 kapita/tahun, sehingga menempatkan Indonesia sebagai konsumen beras terbesar dunia [14]. Pembangunan pertanian diharapkan dapat menunjang terciptanya sektor pengolahan padi sebagai sektor yang dapat menyediakan kebutuhan pangan nasional. Pemerintah terus mengupayakan terciptanya swasembada beras dengan menjaga stabilitas pasokan dan harga beras agar mengurangi kerawanan pangan di kemudian hari [15]. Food and Agriculture Organization (FAO) menyatakan bahwa di awal tahun 2018 harga beras Indonesia masih relatif tinggi jika dibandingkan dengan rata-rata harga beras internasional. Status perdagangan Indonesia sama dengan Filipina akan tetapi harga beras di Filipina relatif lebih rendah, yaitu USD 0,82 per kilogram dengan harga beras Indonesia mencapai 
USD 1,01 per kilogram [16]. Secara umum harga pangan dunia terbilang wajar setidaknya sampai Maret 2020, namun semenjak jalur perdagangan internasional terhambat akibat penyebaran SARS-CoV-2, virus penyebab pandemi Covid-19, negara-negara di dunia berusaha memenuhi kebutuhan pangan dalam negeri. Berdasar data dari Food and Agriculture Organization (FAO), harga pangan mulai mengalami peningkatan sejak Oktober 2019 hingga Januari 2020, kemudian mulai melandai pada bulan Februari dan Maret 2020. Hasil analisis secara spesifik dari rice price index, komoditas pangan utama seperti beras mulai mengalami peningkatan sebesar 3\% dalam tiga bulan terakhir yaitu bulan Januari hingga Maret 2020. Harga beras yang tidak stabil jelas dapat menimbulkan masalah. Oleh karena itu, untuk menekan harga beras supaya tetap stabil dilakukan peramalan atau prediksi terhadap rata-rata harga beras di Indonesia pada masa mendatang.

Penelitian mengenai fuzzy time series telah dilakukan sebelumnya, antara lain oleh Hilal Guney, Mehmet Akif Bakir, Cagdas Hakan Aladag [17] yaitu fuzzy time series Markov chain menggunakan deret waktu musiman pada kuartalan produksi bir Amerika Serikat dan jumlah turis asing yang mengunjungi Turki menghasilkan transisi matriks yang lebih akurat. Maharni [18]membahas metode fuzzy time series Markov chain berdasarkan average based yang dibandingkan dengan fuzzy time series Markov chain berdasarkan Gauss membership function pada data inflasi Indonesia. Hasil penelitian terbukti bahwa metode average based memiliki tingkat keakuratan lebih tinggi jika dibandingkan dengan metode Gauss membership function. Woo-Joo Lee, Jung Hye-Young, Jin Hee Yoon, dan Seung Hoe Choi [19]mengembangkan fuzzy time series menggunakan algoritma novel berdasarkan F-Transform untuk meramalkan pendaftaran mahasiswa baru universitas Alabama Taiwan. Hasil penelitian menunjukkan bahwa metode ini lebih unggul jika dibandingkan metode yang lain. Berdasarkan uraian latar belakang, maka dikaji "Perbandingan Tingkat Akurasi Metode Average Based Fuzzy Time Series Markov Chain dan Algoritma Novel Fuzzy Time Series (Studi Kasus: Harga Beras di Tingkat Perdagangan Besar Indonesia)." Dengan penelitian ini, diharapkan pemerintah dapat sedini mungkin menentukan kebijakan yang tepat terkait harga beras, mengingat pentingnya pencegahan atas kemungkinan terburuk akibat ketidakstabilan harga beras. Oleh karena itu, setiap kenaikan dan penurunan harga beras di masa mendatang dapat diantisipasi oleh masyarakat, baik dari konsumen maupun pelaku bisnis sehingga dapat dilakukan pengontrolan harga beras di masa mendatang.

\section{METODE}

\section{Langkah-langkah penelitian}

Pendekatan penelitian yang digunakan dalam penelitian ini adalah pendekatan studi literatur dan analisis kuantitatif. Penelitian diawali dengan studi literatur, yaitu pengumpulan informasi dan referensi melalui bahan pustaka dan beberapa situs internet yang relevan dengan penelitian. Sedangkan pendekatan analisis kuantitatif ini berdasarkan uji data terhadap objek yang diteliti. Jenis data yang digunakan dalam penelitian ini merupakan data sekunder, yang datanya sudah ada, baik berupa buku, artikel jurnal, situs internet maupun data hasil publikasi lembaga pemerintahan. Sumber data sekunder diperoleh dari Badan Pusat Statistik (BPS) berupa data rata-rata harga beras bulanan di tingkat perdagangan besar atau grosir mulai bulan Januari 2015 sampai Maret 2021,yang diambil secara online di situs resmi Badan Pusat Statistik (BPS) yaitu http://bps.go.id. Langkah-langkah penelitian

a. Menganalisis deskriptif data.

b. Menghitung data menggunakan metode Average based Fuzzy Time Series Markov Chain. Langkah-langkah metode fuzzy time series Markov chain adalah sebagai berikut:

1. Membentuk himpunan semesta $U$, untuk menentukkan data minimum dan data maksimum dari data historis agar mendapatkan $D_{\min }$ dan $D_{\max }$ dengan menggunakan persamaan berikut:

$$
U=\left[D_{\min }-D_{1}, D_{\max }-D_{2}\right]
$$

di mana $D_{\min }$ dan $D_{\max }$ merupakan data terkecil dan data terbesar dari himpunan semesta $U$, dengan $D_{1}$ dan $D_{2}$ merupakan bilangan acak dari himpunan semesta yang bernilai positif 
2. Membentuk interval dengan menghitung jumlah partisi setiap interval menggunakan metode average based. Average based merupakan salah satu algoritma pada metode fuzzy time series untuk menentukan interval berdasarkan rata-rata. Proses penentuan interval dapat dilakukan dengan tahapan sebagai berikut:

a. Menghitung keseluruhan selisih nilai absolut antara $A_{i+1}$ dan $A_{i}(i=1 \ldots, n-1)$ sehingga didapatkan rata-rata dari selisih nilai absolut:

$$
\text { Mean }=\frac{\sum_{i=1}^{n}\left|D_{t}-D_{t-1}\right|}{n-1}
$$

b. Menghitung setengah dari rata-rata selisih nilai absolut yang telah didapatkan pada langkah pertama menjadi panjang interval, sesuai dengan rumus:

$$
\ell=\frac{\text { Mean }}{2}
$$

dengan $\ell$ menyatakan panjang interval.

c. Menentukan panjang interval sesuai basis intervalnya berdasarkan panjang interval dari langkah kedua. Basis dari panjang interval dapat ditentukan sesuai dengan tabulasi basis. Tabel (1) menjelaskan tentang panjang jangkauan dan basisnya, lebih jelasnya ditunjukkan pada tabel di bawah ini.

Tabel 1. Basis Interval

\begin{tabular}{cc}
\hline \multicolumn{2}{c}{ Basis Interval } \\
\hline Jangkauan & Basis \\
$0.1-1.0$ & 0.1 \\
$1.1-10$ & 1 \\
$11-100$ & 10 \\
$101-1000$ & 100 \\
\hline
\end{tabular}

d. Bulatkan panjang interval menurut basis intervalnya sesuai pada Tabel (1).

3. Menentukan jumlah interval fuzzy dapat dihitung dengan persamaan:

$$
n=\frac{\left[\left(D_{\max }+D_{1}-D_{\min }+D_{2}\right)\right]}{I},
$$

kemudian himpunan semesta $U$ dipartisi menjadi $n$ interval dan panjang interval $I$, dengan setiap interval diperoleh sesuai persamaan berikut:

$$
\begin{gathered}
u_{1}=\left[D_{\text {min }}-D_{1}, D_{\text {min }}-D_{1}+I\right] \\
u_{2}=\left[D_{\text {min }}-D_{1}+I, D_{\text {min }}-D_{1}+2 I\right] \\
\cdots \\
u_{n}=\left[D_{\text {min }}-D_{1}+(n-1) I, D_{\text {min }}-D_{1}+n I\right]
\end{gathered}
$$

4. Menentukan himpunan fuzzy. Pendefinisian himpunan fuzzy dilakukan untuk mengetahui nilai keanggotaan pada setiap himpunan fuzzy yang menyatakan variabel linguistik $1 \leq$ $i \leq n$ dengan nilai keanggotaan yang disederhanakan diantara nilai $0,0.5$, dan 1 .

5. Menentukan fuzzifikasi. Fuzzifikasi bertujuan untuk mengubah variabel numerik menjadi linguistik menggunakan nilai keanggotaan himpunan fuzzy.

6. Menentukan Fuzzy Logical Relationship (FLR) sesuai hubungan antar setiap urutan data setiap data dengan data selanjutnya.

7. Menentukan Fuzzy Logical Relationship Group (FLRG) berdasarkan pengelompokkan hubungan antar state ke state yang sama.

8. Menghitung nilai matriks probabilitas transisi pada langkah sebelumnya menggunakan Fuzzy Logical Relationship Group (FLRG).

9. Menghitung peramalan awal berdasarkan FLR, FLRG, dan matriks probabilitas transisi yang telah diperoleh. Peramalan awal $F_{t}$ dengan $t=1,2,3, \ldots, N$ nilai hasil peramalan pada $F_{t}$ dapat ditentukan dengan menggunakan beberapa aturan sebagai berikut:

Aturan 1. Apabila terdapat FLRG dari himpunan fuzzy $A_{i}$ yaitu himpunan kosong $A_{i} \rightarrow \emptyset$, dengan periode data $(t-1)$ pada $A_{i}$, maka hasil peramalan $F_{t}$ adalah $m_{i(t-1)}$ nilai tengah interval $u_{i}$ yang berada pada FLRG data $t-1$. 
Aturan 2. Apabila terdapat FLRG dari himpunan fuzzy $A_{i}$ adalah satu-satu $A_{i} \rightarrow A_{p}$, dengan $P_{i p}=1$ dan $P_{i j}=0, j \neq p$, maka $Y_{(t-1)}$ dari periode data $(t-1)$ pada state $A_{i}$, maka hasil peramalan $F_{t}$ adalah $m_{p(t-1)}$, di mana $m_{p(t-1)}$ nilai tengah interval $u_{p}$ dari FLRG.

Aturan 3. Apabila terdapat FLRG dari himpunan fuzzy $A_{i}$ adalah suku banyak $A_{j} \rightarrow$ $A_{1}, A_{2}, \ldots, A_{q}$ dengan periode data $(t-1)$ pada $A_{i}$, hasil peramalan $F_{t}$ adalah.

$$
\begin{aligned}
F_{t}= & m_{i(t-1)} P_{j 1}+m_{i(t-1)} P_{j 2}+\cdots+m_{j-1(t-1)} P_{j-1(j-1)} \\
& +Y_{(t-1)} P_{j j}+m_{j+i(t-1)} P_{j(j+1)}+\cdots+m_{q(t-1)} P_{j q}
\end{aligned}
$$

di mana, $m_{j-1}, m_{j+i}$ adalah nilai tengah $u_{j-1}$ dan $F_{t}$ adalah nilai dari state $A_{i}$ pada waktu $(t-$ 1).

10. Menyesuaikan kecenderungan nilai peramalan dilakukan untuk memperbaiki error atau memperkecil kesalahan peramalan. Beberapa penyesuaian untuk meninjau kembali kesalahan peramalan dilakukan dengan aturan sebagai berikut:

Aturan 1. Apabila nilai transisi diawali $s t a t e A_{i}$ dengan periode data $(t-1)$ pada $F_{t-1}=A_{i}$, serta dapat membentuk transisi yang melompat maju ke state $A_{i+s}$ dengan periode $t$ di mana $i \leq s \leq p-i$. Sehingga nilai kecenderungan $D_{t}$ dapat ditulis:

$$
D_{t 2}=\left(\frac{l}{2}\right) s,
$$

dengan $s$ merupakan jumlah lompatan maju

Aturan 2. Apabila nilai transisi diawali $\operatorname{state}_{i}$ dengan periode data $(t-1)$ pada $F_{t-1}=A_{i}$, serta dapat membentuk transisi yang melompat mundur dengan state $_{i-v}$ dengan periode $t$ yang mana $1 \leq v \leq i$. Sehingga nilai kecenderungan $D_{t}$ dapat ditulis:

$$
D_{t 2}=-\left(\frac{l}{2}\right) s
$$

dengan $l$ merupakan jumlah lompatan mundur.

11. Membuat hasil peramalan akhir dari kecenderungan nilai peramalan yang telah disesuaikan. Apabila terdapat FLR dari himpunan fuzzy $A_{i}$ adalah suku banyak dan state $_{i+1}$ yang diperoleh dari $A_{i}$ yang mana state $_{i}$ tidak berkaitan dengan $A_{i}$ maka hasil perhitungan:

$$
F^{\prime}(t)=F_{t}+D_{t 2}=F_{t}+\frac{l}{2}
$$

c. Menghitung data menggunakan metode Algoritma Novel berdasarkan Fuzzy Time Series. Langkah-langkah prediksi menggunakan algoritma novel berdasarkan fuzzy time series adalah sebagai berikut:

1. Menentukan himpunan semesta.

2. Memartisi himpunan semesta $U$ menjadi beberapa interval sama panjang.

3. Menentukan jumlah himpunan fuzzy berdasarkan interval yang telah di partisi.

4. Menentukan himpunan fuzzy dari keseluruhan himpunan semesta.

5. Memilih Fuzzy Logical Relationship (FLR).

6. Menentukan Fuzzy Logical Relationship Group (FLRG).

7. Perhitungan hasil peramalan pada waktu $t$ menggunakan ketentuan sebagai berikut:

Ketentuan 1. Apabila terdapat FLRG himpunan fuzzy $A_{i}$ adalah kosong $A_{i} \rightarrow \emptyset$, maka hasil perhitungan berada di tengah interval $A_{i}$, di mana:

$$
A_{i}=\left(d_{i-1}, d_{i}, d_{i+1}, d_{i+2}\right) \text {. }
$$

Ketentuan 2. Apabila terdapat FLRG himpunan fuzzy $A_{i}$ adalah satu-satu $A_{i} \rightarrow A_{1}$, maka interval perhitungan peramalan dapat dinotasikan dengan $A_{j}$. Hasil peramalan untuk langkah pertama akan dibandingkan dengan nilai $j$ dan $i$ pada current state dan next state. Setelahnya tentukan nilai $Y$ menggunakan rumus:

$$
Y=\left(D_{t}-D_{t-1}\right)-\left(D_{t-1}-D_{t-2}\right) \text {. }
$$

Menggunakan aturan sebagai berikut:

a. Apabila $j>i$ dan $Y>0$, maka perhitungan peramalan menggunakan aturan 2 akan cenderung naik.

b. Apabila $j>i$ dan $Y<0$, maka perhitungan peramalan menggunakan aturan 3 akan cenderung turun. 
c. Apabila $j<i$ dan $Y>0$, maka perhitungan peramalan menggunakan aturan 2 cenderung akan naik.

d. Apabila $j<i$ dan $Y<0$, maka perhitungan peramalan menggunakan aturan 3 akan cenderung turun.

e. Apabila $j=i$ dan $Y>0$, maka perhitungan peramalan menggunakan aturan 2 akan cenderung naik.

f. Apabila $j=i$ dan $Y<0$, maka perhitungan peramalan menggunakan aturan 3 akan cenderung turun.

Adapun ketentuan yang dapat digunakan untuk melakukan peramalan, di antaranya:

\section{Aturan 1}

Aturan 1 digunakan apabila $Y$ tidak terpenuhi. Aturannya sebagai berikut:

a. Apabila $x>\frac{A_{j}}{2}$ dengan $x=\frac{D_{t}-D_{t-1}}{2}$, maka perhitungan hasil peramalan perhitungan interval akan naik dan jatuh pada poin 0,75 dari interval $A_{j}$.

b. Apabila $x=\frac{A_{j}}{2}$ maka perhitungan hasil peramalan merupakan nilai tengah interval $A_{j}$.

c. Apabila $x<\frac{A_{j}}{2}$ maka hasil perhitungan peramalan pada poin 0,25 dari interval $A_{j}$ cenderung turun dan jatuh.

\section{Aturan 2}

a. Apabila $x \in A_{j}$ dengan $x=|Y| \times 2+D_{t-1}$ atau $x=D_{t-1}-|Y|$, maka perhitungan hasil peramalan cenderung naik dan jatuh pada poin ke 0,75 di interval $A_{j}$.

b. Apabila $x \in A_{j}$ dengan $x=\frac{|Y|}{2}+D_{t-1}$ atau $x=D_{t-1}-|Y| \times 2$, maka perhitungan hasil peramalan cenderung turun dan jatuh pada poin ke 0,25 di interval $A_{j}$.

c. Apabila dari kedua kondisi tersebut masih belum terpenuhi maka nilai dari titik tengah di interval $A_{j}$ merupakan hasil peramalan.

\section{Aturan 3}

a. Apabila $x \in A_{j}$ dengan $x=\frac{|Y|}{2}+D_{t-1}$ atau $x=D_{t-1}-\frac{|Y|}{2}$, maka perhitungan hasil peramalan cenderung turun dan jatuh pada poin ke 0,25 di interval $A_{j}$.

b. Apabila $x \in A_{j}$ dengan $x=|Y| \times 2+D_{t-1}$ atau $x=D_{t-1}-|Y| \times 2$, maka perhitungan hasil peramalan cenderung naik dan jatuh pada poin ke 0,75 di interval $A_{j}$.

c. Apabila dari kedua kondisi tersebut masih belum terpenuhi maka nilai dari titik tengah di interval $A_{j}$ merupakan hasil peramalan.

Ketentuan 3. Apabila terdapat FLRG dari himpunan fuzzy $A_{i}$ adalah suku banyak $A_{i} \rightarrow$ $A_{1}, A_{2}, \ldots, A_{k}$. maka didapatkan hasil peramalan sebagai berikut:

a. Apabila selisih dari $2 j_{1}, j_{2}, \ldots, j_{p}, \leq 2$, maka hasil peramalan adalah nilai tengah dari interval tersebut.

b. Apabila selisih dari $2 j_{1}, j_{2}, \ldots, j_{p}, \leq 2$, maka hasil peramalan FLR pada langkah ke-tujuh sesuai dengan aturan 2.

d. Analisis perbandingan akurasi metode Average based Fuzzy Time Series Markov Chain dan Algoritma Novel berdasarkan Fuzzy Time Series menggunakan uji keakuratan Mean Absolute Percentage Error (MAPE) sehingga dari kedua metode tersebut dapat diketahui metode perhitungan yang paling akurat. Rumus Mean Absolute Percentage Error (MAPE) adalah sebagai berikut:

Keterangan:

$$
M A P E=\frac{1}{n} \sum_{t=1}^{n} \frac{|Y(t)-F(t)|}{Y(t)} \times 100 \%
$$

$Y(t)=$ Data aktual periode $t$.

$F(t)=$ Hasil peramalan pada periode $t$.

$n \quad=$ Banyak periode peramalan. 
Kriteria tingkat keakuratan MAPE dianggap baik apabila memiliki nilai standar error kecil, semakin kecil nilai, semakin baik hasil peramalan. Kriteria MAPE disajikan dalam tabel berikut.

Tabel 2.Kriteria MAPE

\begin{tabular}{cc}
\hline MAPE & Keterangan \\
\hline $10 \%$ & Sangat Baik \\
$10 \%-20 \%$ & Baik \\
$20 \%-50 \%$ & Cukup Baik \\
$>50 \%$ & Buruk \\
\hline
\end{tabular}

\section{HASIL DAN PEMBAHASAN}

\section{Analisis Deskriptif}

Data yang diterapkan dalam penelitian ini merupakan data rata-rata harga beras bulanan di tingkat perdagangan besar atau grosir mulai bulan Januari 2015 hingga Maret 2021 dalam satuan Rp/kg sejumlah 75 data. Data penelitian diperoleh dari Badan Pusat Statistik (BPS) yang dianalisis menggunakan metode average based fuzzy time series Markov chain dan algoritma novel fuzzy time series. Gambar plot time series sebagai berikut:

\section{PLOT TIME SERIES RATA-RATA HARGA BERAS DI INDONESIA}

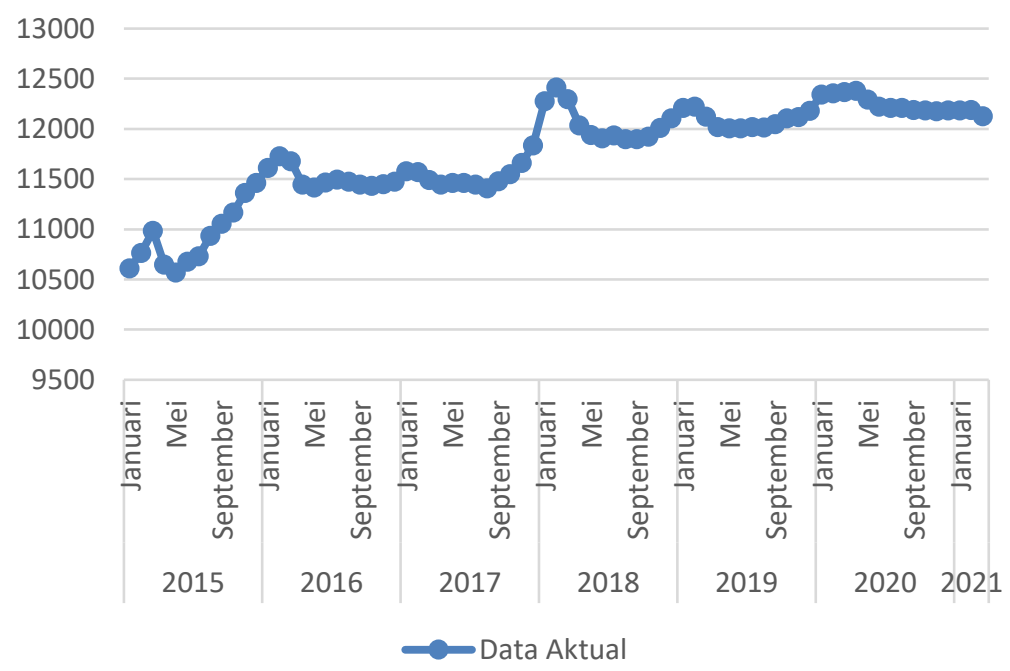

Gambar 1.Plot Time Series Data Rata-rata Harga Beras

Berdasarkan Gambar (1), dapat dilihat bahwa pola data rata-rata harga beras di tingkat perdagangan besar Indonesia mulai bulan Januari 2015 sampai bulan Maret 2021 mengalami fluktuasi. Secara keseluruhan dari periode 2015 hingga 2021 data rata-rata harga beras memiliki harga termurah pada bulan Mei 2015sebesar Rp10.569,00 dan harga termahal pada bulan Februari 2018 sebesar Rp12.414,00. Periode 2015 sampai 2021 dipilih karena pada periode tersebut mencerminkan kondisi perkembangan harga beras ketika terjadi fluktuasi pada pergerakan ekonomi, ditambah adanya penyebaran pandemi Covid-19 gelombang pertama yang menimbulkan gejolak pasar beras global pada Maret hingga April 2020 yang dikhawatirkan akan berakibat pada krisis pangan di Indonesia. 


\section{Perhitungan Metode Average Based Fuzzy Time Series Markov Chain}

Langkah-langkah peramalan rata-rata harga beras menggunakan metode average based fuzzy time series Markov chain adalah sebagai berikut:

Langkah 1. Menentukan himpunan semesta $U$ dari data historis.

Berdasarkan data harga beras bulan Januari 2015 sampai Maret 2021 didapatkan nilai minimum $\left(D_{\text {min }}\right)$ pada bulan Mei 2015 yaitu 10.569 dan nilai maksimum $\left(D_{\text {maks }}\right)$ pada bulan Februari 2018 yaitu 12.414. $D_{1}$ dan $D_{2}$ yang merupakan bilangan positif yang sesuai, maka ditentukan nilai $D_{1}=$ 69dan $D_{2}=86$. Persamaan himpunan semesta $U$ dapat didefinisikan sebagai

$$
\begin{aligned}
U & =\left[D_{\min }-D_{1}, D_{\text {maks }}+D_{2}\right] \\
& =[10.569-69,12.414+86] \\
& =[10.500,12.500] .
\end{aligned}
$$

Langkah 2.Menentukan panjang interval (I).

Metode penentuan panjang interval yang digunakan adalah metode average based. Langkah pertama perhitungan average based adalah menghitung keseluruhan selisih nilai absolut antara $D_{t+1}$ dan $D_{t}(t=1, \ldots, 75)$, diperoleh jumlah data dari seluruh selisih nilai absolut yaitu 5529, sehingga rata-rata yang didapatkan sebesar 75 . Kemudian dihitung setengah dari rata-rata selisih nilai mutlak tersebut sehingga diperoleh 37,5. Berdasarkan Tabel (1) maka panjang jangkauan dan basis interval yang digunakan adalah 10 kemudian dari 37,5 dapat dibulatkan sesuai dengan basis interval, sehingga didapatkan panjang interval (I) yaitu 40.

Langkah 3. Menentukan jumlah interval.

Berdasarkan Persamaan (4) maka jumlah interval $(m)$ dari seluruh himpunan semesta $U$ untuk setiap data sebanyak 50 interval yaitu $u_{1}, u_{2}, u_{3}, \ldots, u_{50}$, dengan panjang interval adalah 40 . Berdasarkan Persamaan (2.14) interval dari seluruh himpunan semesta $U$ adalah $u_{1}=$ $[10.500 ; 10.540], u_{2}=[10.540 ; 10.580], u_{3}=[10.580 ; 10.620] \ldots, u_{50}=[12.460 ; 12.500]$.

Selanjutnya dihitung nilai tengah $(\mathrm{m})$ setiap interval himpunan semesta $U$ dengan Persamaan (2.4). Hasil nilai tengah $(m)$ dari masing-masing himpunan semesta $U$ adalah $d_{1}=10.520, d_{2}=$ $10.560, d_{3}=10.600, \ldots, d_{50}=12.480$.

\section{Langkah 4. Menentukan himpunan fuzzy.}

Berdasarkan jumlah interval yang diperoleh, maka interval yang digunakan untuk menentukan derajat keanggotaan himpunan fuzzy terhadap $A_{i}$ adalah 50 interval yaitu $u_{1}, u_{2}, u_{3} \ldots, u_{50}$. Setiap himpunan fuzzy $_{i}$ untuk $1 \leq i \leq 50$ dengan pendefinisian derajat keanggotaan himpunan fuzzy terhadap $A_{i}$ yang terbentuk.

$$
\begin{aligned}
& A_{1}=\left\{1 / u_{1}+0,5 / u_{2}+0 / u_{3}+0 / u_{4}+\cdots+0 / u_{50}\right\} \\
& A_{2}=\left\{0,5 / u_{1}+1 / u_{2}+0,5 / u_{3}+0 / u_{4}+\cdots+0 / u_{50}\right\} \\
& A_{3}=\left\{0 / u_{1}+0,5 / u_{2}+1 / u_{3}+0,5 / u_{4}+\cdots+0 / u_{50}\right\} \\
& \begin{array}{lllllll}
\vdots & \vdots & \vdots & \vdots & \vdots & \cdots & \vdots
\end{array} \\
& A_{50}=\left\{0 / u_{1}+0 / u_{2}+0 / u_{3}+0 / u_{4}+\cdots+1 / u_{50}\right\}
\end{aligned}
$$

Di mana $u_{i}$ merupakan himpunan fuzzy ke- $i$ dengan simbol "/" yang menyatakan derajat keanggotaan $u_{i}$ terhadap $A_{i}=1,2,3, \ldots, 50$ yang bernilai $0,0,5$, atau 1 . Himpunan fuzzy ini merupakan himpunan yang nantinya digunakan sebagai bahan acuan untuk proses fuzzifikasi.

Langkah 5.Melakukan fuzzifikasi terhadap data historis.

Fuzzifikasi data merupakan proses menentukan nilai linguistik setiap data rata-rata harga beras yang semula berbentuk interval diubah ke dalam bentuk nilai linguistik yang diperoleh dari pendefinisian derajat keanggotaan himpunan fuzzy terhadap $A_{i}$. Misalkan data bulan Januari 2015 yaitu 10.612 di mana data $t=1$ terletak pada interval $u_{3}=[10.580,10.620]$. Himpunan fuzzy yang terbentuk pada $u_{3}$ mempunyai derajat keanggotaan maksimum sebesar 1 terhadap himpunan $A_{3}$. Berdasarkan derajat keanggotaan maksimum tersebut, maka hasil fuzzifikasi data pada bulan Januari 2015 yang berada pada interval $[10.580,10.620]$ adalah $A_{3}$. 
Langkah 6. Menentukan Fuzzy Logical Relationship (FLR).

Fuzzy logical relationship (FLR) merupakan hubungan antara setiap urutan data terhadap data berikutnya dalam bentuk himpunan fuzzy. Fuzzy logical relationship (FLR)dapat ditulis dengan $A_{i} \rightarrow A_{j}$, di mana $A_{i}$ adalah state saat ini (current state) dan $A_{j}$ adalah state selanjutnya (next state) dari FLR. Misalkan data pada bulan Januari $2015(t=1)$ memiliki himpunan fuzzy $A_{3}$ dan data pada bulan Februari $2015(t=2)$ memiliki himpunan fuzzy $A_{7}$, maka FLR yang diperoleh yaitu $A_{3} \rightarrow A_{7}$.

Langkah 7. Menentukan Fuzzy Logical Relationship Group (FLRG).

FLRG yang merupakan pengelompokan dari setiap perpindahan state, yaitu state saat ini (current state) dan state selanjutnya (next state). Misalkan ketika FLR himpunan fuzzy yang bernilai $A_{23}$ (current state) mempunyai perpindahan ke $A_{25}$ (next state) dihitung menurut banyaknya kemunculan nilai FLR dengan perpindahan state. Nilai FLR dengan perpindahan $A_{23}$ ke $A_{25}$ terdapat 2 kali kemunculan, maka FLRG dari $A_{23}$ (current state) ke $A_{25}$ (next state) dapat ditulis $A_{23} \rightarrow(2) A_{25}$.

Langkah 8. Membentuk matriks probabilitas.

Matriks probabilitas transisi pada penelitian ini berorde $50 \times 50$ dengan setiap elemen $P_{i j}=\frac{M_{i j}}{M_{i}}$ merupakan nilai probabilitas setiap kejadian dari interval data sebelumnya, maka digunakan FLRG untuk membentuk matriks probabilitas transisi Markov. Berdasarkan nilai probabilitas pada matriks probabilitas transisi yang terbentuk, maka nilai peramalan awal pada data historis dapat dihitung.

Langkah 9. Menghitung nilai peramalan awal.

Peramalan awal metode average based fuzzy time series Markov chain ini menggunakan data sebelumnya dan matriks probabilitas transisi berdasarkan nilai probabilitas pada langkah 8. Peramalan awal dilakukan sesuai dengan data historis merujuk pada Persamaan (6). Perhitungan ini menggunakan data aktual sebelumnya $t-1$, oleh karena itu peramalan dapat dilakukan mulai dari data $t=2$ yaitu bulan Februari 2015. Misalkan data rata-rata harga beras untuk $t=2$ memiliki nilai yaitu 10.760 dan $t=1$ memiliki nilai yaitu 10.612 , di mana pada data $t=1$ memiliki FLR $A_{3} \rightarrow A_{7}$ yang artinya $A_{3}$ bertransisi menuju $A_{7}$, dan karena FLRG yang diperoleh hanya $A_{3} \rightarrow A_{7}$. Nilai perhitungan peramalan Februari $2015(t=2)$ adalah

$$
\begin{aligned}
F_{2} & =m_{1} P_{37} \\
& =10760(1) \\
& =10760 .
\end{aligned}
$$

Pola perbandingan antara data aktual dengan nilai peramalan menggunakan metode average based fuzzy time series Markov chain dapat divisualisasikan sebagai berikut: 


\section{GRAFIK PERBANDINGAN ANTARA DATA \\ AKTUAL DENGAN PERAMALAN AWAL AVERAGE \\ BASED FUZZY TIME SERIES MARKOV CHAIN}

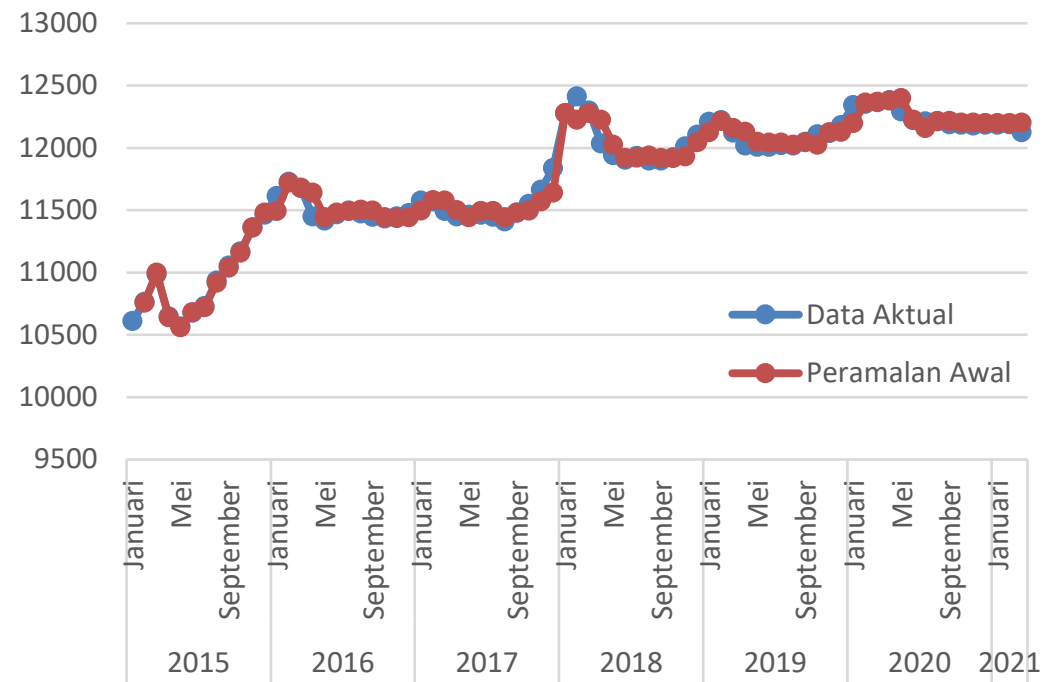

Gambar 2. Grafik Perbandingan Data Aktual dan Peramalan Awal Metode Average Based Fuzzy Time Series

\section{Langkah 10.Menyelesaikan kecenderungan nilai peramalan.}

Metode fuzzy time series Markov chain mempunyai langkah penyesuaian kecenderungan nilai peramalan sebagai tahapan untuk mengurangi besarnya penyimpangan hasil peramalan. Penyesuaian kecenderungan nilai peramalan dilakukan pada setiap hubungan antara current state dan next state dari FLR berdasarkan Persamaan (7) dan Persamaan (8). Misalkan perhitungan nilai penyesuaian bulan Februari 2015, nilai FLR dari next state adalah $A_{7}$ dan current state adalah $A_{3}$. Hal ini mengakibatkan persamaan yang digunakan untuk menghitung nilai penyesuaian peramalan adalah Persamaan (2.20) sebagaimana $s=$ orde state selanjutnya orde state saat ini $=7-3=4$, maka perhitungan nilai penyesuaian yang diperoleh

$$
\begin{aligned}
D_{t 1} & =\left(\frac{l}{2}\right) \times 4 \\
& =\left(\frac{50}{2}\right) \times 4 \\
& =100 .
\end{aligned}
$$

Langkah 11.Menentukan hasil peramalan akhir.

Hasil peramalan akhir merupakan hasil perhitungan dari peramalan awal yang dijumlahkan dengan nilai penyesuaian yang telah disesuaikan mengacu pada Persamaan (9). Misalkan perhitungan nilai peramalan pada bulan Februari 2015 yang telah disesuaikan sebagai berikut:

$$
\begin{aligned}
F_{2}^{\prime} & =F_{2} \pm D_{t 1} \\
& =10760 \pm 100 \\
& =10.860 .
\end{aligned}
$$

Hasil perhitungan peramalan akhir pada bulan Februari 2015 adalah 10.860, dengan menggunakan cara yang sama didapatkan hasil dari nilai peramalan akhir. Pola perbandingan antara data aktual dengan nilai peramalan menggunakan metode average based fuzzy time series Markov chain dapat divisualisasikan sebagai berikut: 


\section{GRAFIK PERBANDINGAN ANTARA DATA \\ AKTUAL DENGAN PERAMALAN AVERAGE BASED \\ FUZZY TIME SERIES MARKOV CHAIN}

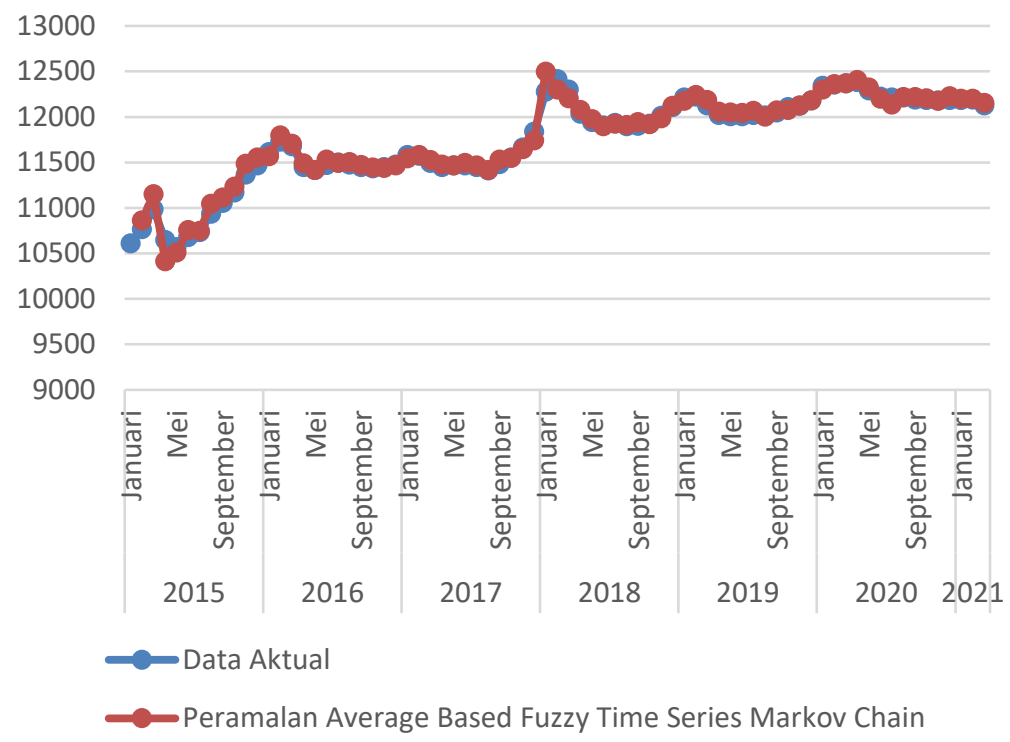

Gambar 3. Grafik Perbandingan Data Aktual dan Peramalan Akhir Average Based Fuzzy Time Series

\section{Perhitungan Metode Algoritma Novel Fuzzy Time Series.}

Metode algoritma novel fuzzy time series digunakan sebagai pembanding untuk mengetahui tingkat akurasi dari setiap metode. Perbedaan yang mendasari antara metode average based fuzzy time series Markov chain dengan algoritma novel fuzzy time series, terdapat pada langkah perhitungan hasil peramalan. Berikut langkah-langkah untuk menghitung hasil peramalan menggunakan metode Algoritma novel fuzzy time series sebagai pembanding untuk mengetahui tingkat akurasi dari setiap metode.

Langkah pertama untuk mempermudah proses peramalan yaitu menghitung seluruh nilai peramalan dari data sebelumnya untuk setiap FLR dan FLRG. Misalkan untuk menghitung nilai peramalan pada bulan Februari 2015, dapat merujuk pada data yang terdapat dalam proses fuzzy logical relationship (FLR) dari bulan Januari 2015 menuju Februari 2015 di mana state bertransisi dari $A_{3}$ ke $A_{7}$. Berdasarkan data FLRG dari $A_{3}$ hanya $A_{7}$, maka FLRG $A_{3}$ bernilai satu ke satu, sehingga perhitungan nilai peramalan mengikuti Ketentuan 2. Langkah berikutnya adalah menghitung nilai $Y$ menggunakan Persamaan (11), namun karena data pada bulan desember 2014 tidak diketahui maka nilai $Y$ tidak dapat dihitung, sehingga hasil peramalan pada bulan Februari 2015 mengikuti Aturan 1. Menurut Aturan 1 dapat dihitung nilai $x$ dengan rumus sebagai berikut:

$$
\begin{aligned}
x & =\frac{D_{t}-D_{t-1}}{2} \\
& =\frac{|10.766-10.612|}{2} \\
& =77 .
\end{aligned}
$$

Nilai $x$ yang diperoleh adalah 77. Selanjutnya menghitung setengah dari interval $A_{7}$ yaitu $u_{7}=$ [10.740; 10.780], didapatkan setengah dari interval $A_{7}$ adalah 10.760 atau sama dengan nilai tengah dari $u_{7}$, maka nilai dari perhitungan tersebut adalah $x<\frac{A_{7}}{2}$. Berdasarkan ketentuan dari Aturan 1, hasil peramalan bulan Februari 2015 cenderung turun dan jatuh pada 0,25 poin dari interval $A_{7}$ yaitu 10.760 . Pola perbandingan antara data aktual dengan nilai peramalan menggunakan metode algoritma novel fuzzy time series dapat divisualisasikan sebagai berikut: 


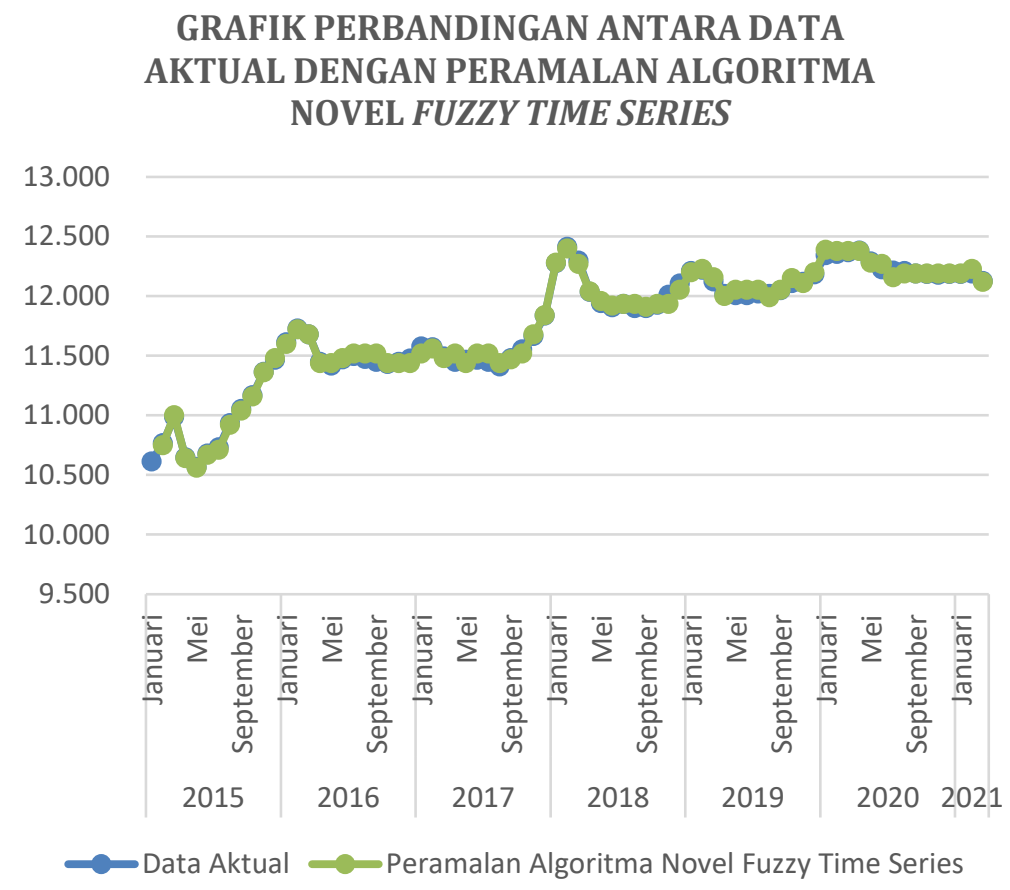

Gambar 4. Grafik Perbandingan Data Aktual dan Algoritma Novel Fuzzy Time Series

\section{Perbandingan Tingkat Akurasi Metode Average Based Fuzzy Time Series Markov Chain dan Algoritma Novel Fuzzy Time Series}

Pengujian tingkat akurasi dilakukan untuk mengetahui keakuratan dari metode average based fuzzy time series Markov chain dengan algoritma novel fuzzy time series sebagai pembanding. Ketepatan perhitungan nilai error sangatlah penting, maka digunakan Mean Absolute Percentage Error (MAPE) sebagai kriteria perhitungan uji akurasi.

Tabel 10. Perbandingan Uji Akurasi

\begin{tabular}{cc}
\hline Metode & $\begin{array}{c}\text { Mean Absolute Percentage Error } \\
\text { (MAPE) }\end{array}$ \\
\hline $\begin{array}{c}\text { Average Based Fuzzy Time Series } \\
\text { Markov Chain }\end{array}$ & $0,36 \%$ \\
Algoritma Novel Fuzzy Time Series & $0,19 \%$ \\
\hline
\end{tabular}

Berdasarkan Tabel (10) metode average based fuzzy time series Markov chain memperoleh nilai MAPE sebesar 0,36\%, menunjukkan bahwa tingkat akurasi mencapai 99,64\% dari data actual, sedangkan algoritma novel fuzzy time series yang mendapat nilai MAPE sebesar 0,19\% artinya tingkat akurasi mencapai 99,81\% dari data aktual. Berdasarkan Tabel (2) masing-masing kriteria keakuratan dari metode average based fuzzy time series Markov chain dan algoritma novel fuzzy time series memenuhi kriteria hasil peramalan yang sangat baik karena nilai MAPE $<10 \%$. Hasil peramalan metode algoritma novel fuzzy time series didapatkan nilai MAPE lebih kecil apabila dibandingkan dengan average based fuzzy time series Markov chain sehingga dapat disimpulkan bahwa metode algoritma novel fuzzy time series lebih baik dalam meramalkan ratarata harga beras bulanan di tingkat perdagangan besar atau grosir.

\section{KESIMPULAN}

Berdasarkan uraian hasil dan pembahasan yang telah dipaparkan, dapat diambil kesimpulan bahwa Hasil tingkat akurasi pada peramalan fluktuasi rata-rata harga beras ditingkat perdagangan besar Indonesia menggunakan nilai Mean Absolute Percentage Error (MAPE) untuk 
metode Algoritma Novel Fuzzy Time Series menghasilkan tingkat akurasi lebih baik dibandingkan dengan metode Average Based Fuzzy Time Series Markov Chain. Nilai MAPE untuk metode untuk metode Algoritma Novel Fuzzy Time Series yaitu 0.19\% dengan tingkat akurasi mencapai 99,81\% dari data aktual, sedangkan nilai MAPE untuk metode Average Based Fuzzy Time Series Markov Chain yaitu $0.36 \%$ dengan tingkat akurasi mencapai 99,63\% dari data aktual.

\section{DAFTAR PUSTAKA}

[1] Maricar, Muhammad Azman, "Analisa Perbandingan Nilai Akurasi Moving Average dan Exponential Smoothing untuk Sistem Peramalan Pendapatan pada Perusahaan XYZ," Jurnal Sistem dan Informatika (JSI), 13(2), 36-45, 2019.

[2] Wei, W. W, "Time series analysis," In The Oxford Handbook of Quantitative Methods in Psychology: Vol. 2, 2006.

[3] Muhammad, Mahadi; Sri Wahyuningsih; and Meiliyani Siringoringo, "Peramalan nilai tukar petani subsektor peternakan menggunakan fuzzy time series lee," Jambura Journal of Mathematics, 3(1), 1-15, 2021.

[4] Song, Q., \& Chissom, B. S, " Fuzzy time series and its models“. Fuzzy sets and systems, 54(3), 269-277, 1993.

[5] Nugroho, Kristiawan, "Model Analisis Prediksi Menggunakan Metode Fuzzy Time Series," Infokam, 12(1), 2016.

[6] Ekananta, Yulian, Penerapan Metode Average-Based Fuzzy Time Series Untuk Prediksi Konsumsi Energi Listrik Indonesia, Diss, Universitas Brawijaya, 2017.

[7] Tsaur, Ruey-Chyn, "A fuzzy time series-Markov chain model with an application to forecast the exchange rate between the Taiwan and US dollar," International journal of innovative computing, information and control, 8(7), 4931-4942, 2012.

[8] Jatipaningrum, Maria Titah, "Peramalan Data Produk Domestik Bruto dengan Fuzzy Time Series Markov Chain," Jurnal Teknologi, 9(1), 31-38, 2016.

[9] Noh, Junaidi, Wijono Wijono, and Erni Yudaningtiyas, "Model Average Based FTS Markov Chain untuk Peramalan Penggunaan Bandwidth Jaringan Komputer," Jurnal EECCIS, 9(1), 31-36, 2015.

[10] Jasim, Haneen T; Abdul G, Jasim Salim; Kais I, Ibrahim, " A novel algorithm to forecast enrollment based on fuzzy time series," Applications and Applied Mathematics: An International Journal, 7(1), 385-397, 2012.

[11] Rukhansah, Nurmalia; Much Aziz Muslim; Riza Arifudin, "Fuzzy Time Series Markov Chain Dalam Meramalkan Harga Saham," Seminar Nasional Ilmu Komputer (Snik 2015), Semarang, Vol, 10, pp, 309-321, 2015.

[12] Yudaruddin, Rizky, "Forecasting untuk Kegiatan Ekonomi dan Bisnis," RV Pustaka Horizon, 2019.

[13] Yasrizal, Yasrizal, "Pengaruh Pembangunan Sektor Pertanian Terhadap Distribusi Pendapatan di Indonesia," Jurnal Bisnis Tani, 3 (1), 56-64, 2017.

[14] Badan Pusat Statistik, "Luas Panen dan Produksi Beras di Indonesia 2019: Hasil Kegiatan Pendataan Statistik Pertanian Tanaman Pangan Terintegrasi Dengan Metode Kerangka Sampel Area. Jakarta: Badan Pusat Statistik", 2019.

[15] Nelly, Sofia; Safrida Safrida; Zakiah Zakiah, "Analisis Faktor-faktor yang Mempengaruhi Fluktuasi Harga Beras di Provinsi Aceh," Jurnal Ilmiah Mahasiswa Pertanian, 3(1), 178191, 2018.

[16] Hermawan, Iwan dan Eka Budiyanti, "Integrasi Harga Beras Era Perdagangan Terbuka dan Dampaknya Terhadap Swasembada dan Kesejahteraan Pelaku Ekonomi Beras," Buletin Ilmiah Litbang Perdagangan, 14(1), 21-46, 2020. 
[17] Guney, Hilal, Mehmet Akif Bakir, dan Cagdas Hakan Aladag, " A novel stochastic seasonal fuzzy time series forecasting model," International Journal of Fuzzy Systems, 20(3), 729$740,2018$.

[18] Maharni, Ellina, Pemilihan Fuzzy Time Series Markov Chain Berbasis Rata-Rata Dan Fuzzy Time Series Markov Chain Dengan Fungsi Keanggotaan Gauss Pada Data Tingkat Inflasi Indonesia, Diss, Universitas Brawijaya, 2019.

[19] Lee, Woo-Joo, dkk, " A novel forecasting method based on F-transform and fuzzy time series," International Journal of Fuzzy Systems, 19(6), 1793-1802, 2017. 